\title{
Begonia elachista Moonlight \& Tebbitt sp. nov., an enigmatic new species and a new section of Begonia (Begoniaceae) from Peru
}

\author{
Peter Watson MOONLIGHT ${ }^{1, *}$, Carlos REYNEL $^{2} \&$ Mark TEBBITT $^{3}$ \\ ${ }^{1}$ Royal Botanic Garden Edinburgh, 20a Inverleith Row, Edinburgh EH3 5LR, UK. \\ ${ }^{2}$ Facultad de Ciencias Forestales, Universidad Nacional Agraria-La Molina, \\ Avenida La Molina, Apartado 456, Lima 12, Peru. \\ ${ }^{3}$ Department of Biological and Environmental Sciences, \\ California University of Pennsylvania, California, PA 15419-1394, USA. \\ ${ }^{*}$ Corresponding author: p.moonlight@,rbge.ac.uk \\ ${ }^{2}$ Email: reynel@lamolina.edu.pe \\ ${ }^{3}$ Email: tebbitt@calu.edu
}

\begin{abstract}
The world's smallest Begonia, Begonia elachista Moonlight \& Tebbitt sp. nov., is described and illustrated from a limestone outcrop in the Amazonian lowlands of Pasco Region, Peru. It is placed within the newly described, monotypic Begonia sect. Microtuberosa Moonlight \& Tebbitt sect. nov. and the phylogenetic affinities of the section are examined. Begonia elachista sp. nov. is considered Critically Endangered under the International Union for the Conservation of Nature (IUCN) criteria.
\end{abstract}

Keywords. Begonia, sectional classification, limestone endemics, Peru, Amazonia.

Moonlight P.W., Reynel C. \& Tebbitt M. 2017. Begonia elachista Moonlight \& Tebbitt sp. nov., an enigmatic new species and a new section of Begonia (Begoniaceae) from Peru. European Journal of Taxonomy 281: 1-13. http:// dx.doi.org/10.5852/ejt.2017.281

\section{Introduction}

Begonia L. is a megadiverse, pantropically distributed genus with 1821 currently accepted species (Hughes et al. 2015). The majority of species are understory herbs and shrubs with many prized in the horticulture industry. L'Héritier de Brutelle described the first Begonia species from Peru, B. octopetala L'Hér., in 1788 (L'Héritier de Brutelle 1788). Since this date, the number of Begonia species known from the country has increased rapidly. Smith \& Schubert (1941) covered 34 species in their treatment of the Begoniaceae of Peru, although it did not cover all species known from the country at the time (e.g. B. albomaculata C.DC., described from Peru in 1906 (de Candolle 1906)). Recent field and herbarium work continues to yield new species (e.g. Tebbitt 2011, 2015, 2016) and new records for Peru (e.g. Tebbitt et al. 2015). Hughes et al. (2015) now list more than 75 species classified in 15 sections from Peru and at least ten species remain undescribed (unpubl. data). The Begonia flora of Peru is now the third largest in the Americas after Brazil (242 species) and Colombia (101 species). This study describes a highly unusual new species (B. elachista Moonlight \& Tebbitt sp. nov.) from a limestone outcrop in lowland Pasco, Peru. 
The phylogenetic relationships within Neotropical Begonia were first investigated in depth by Moonlight et al. (2015), who used three cpDNA markers and identified two clades of American Begonia within paraphyletic African Begonia: Neotropical Clade 1 (NC1) and Neotropical Clade 2 (NC2). This study presents a phylogeny of $\mathrm{NC} 2$ with increased sampling. We demonstrate that B. elachista sp. nov. is distantly related to all other tuberous western South American species and sections of Begonia; is resolved outside all closely related sections; and, given the species' unusual morphology, we describe a new section to encompass it (B. sect. Microtuberosa Moonlight \& Tebbitt sect. nov.).

\section{Materials and methods}

\section{Phylogenetics}

The dataset consisted of data from three non-coding plastid DNA regions ( $n d h \mathrm{~A}$ intron, $n h d \mathrm{~F}-r p l 32$ spacer and rpl32-trnL spacer) and 68 species of Begonia (see Appendix). Species were chosen to be representative of all major groups within NC2 with B. sect. Augustia (Klotzsch) A.DC. chosen as an outgroup. A particular emphasis was placed upon the inclusion of other tuberous, western South American species and sections of Begonia. Ninety two sequences were newly generated for this analysis following the methods described in Moonlight et al. (2015).

Sequences were aligned manually in BioEdit v.7.2.5 (Hall 1999). Bayesian phylogenetic reconstruction was carried out in MrBayes v.3.2.1. (Huelsenbeck \& Ronquist 2001). Models of molecular evolution were determined with jModelTest 2.1.7 (Darriba et al. 2012) on a maximum-likelihood topology with the Bayesian information criterion, resulting in the selection of the GTR $+\mathrm{I}+\Gamma$ model. Two searches each comprising two Markov chain Monte Carlo chains were run for $2.5 \times 10^{7}$ generations and sampled every 2500 generations with the burn-in determined as $6.25 \times 10^{6}$ generations following analysis of time series plots in Tracer v.1.6 (Rambaut \& Drummond 2013) to ensure adequate sample size.

\section{Taxonomic descriptions}

The descriptions of B. sect. Microtuberosa sect. nov. and B. elachista sp. nov. presented herein are derived from herbarium material, material grown at the Royal Botanic Garden Edinburgh, and field observations made by the authors during an expedition to Peru in 2016. Stable links to specimens held at $\mathrm{E}$ are included as hyperlinks and images of all cited specimens are available from Hughes et al. (2015). Comparisons to other sections of Begonia were made by reference to Doorenbos et al. (1998) and through reference to living material grown at the Royal Botanic Garden Edinburgh and Glasgow Botanic Gardens.

\section{Results}

\section{Phylogenetics}

The topology of the $50 \%$ majority rule consensus tree (Fig. 1) is entirely consistent with that of Moonlight et al. (2015). We resolve B elachista sp. nov. within a clade of exclusively eastern South American species. The monophyly of $B$. elachista sp. nov. is well-supported $(\mathrm{p}=1.00)$ and it is resolved as sister to three species of $B$. sect. Gaerdtia (Klotzsch) A.DC., which will form the reinstated B. sect. Pereira Brade (Moonlight et al. in prep.), and B. sect. Trachelocarpus (Müll.Berol.) A.DC. as reciprocally monophyletic groups. This placement is moderately well-supported $(\mathrm{p}=0.88)$. We resolve all other tuberous western South American species within a distantly-related clade containing all sampled members of $B$. sect. Eupetalum (Lindl.) A.DC.; $B$. sect. Barya (Klotzsch) A.DC.; all western South American members of $B$. sect. Knesebeckia (Klotzsch) A.DC.; and B. thyrsoidea Irmsch., the only Andean member of B. sect. Quadriperigonia Ziesenh. 


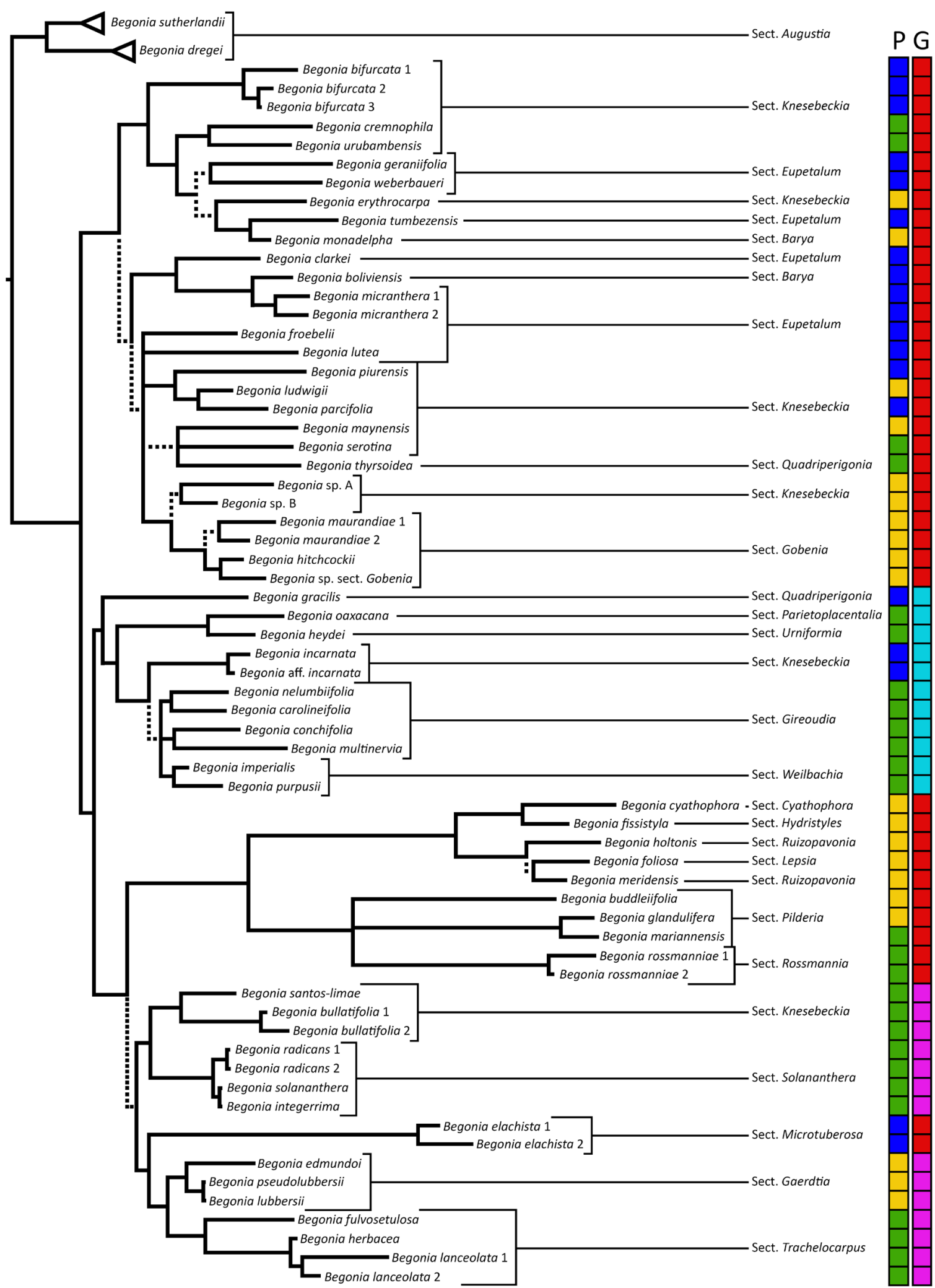

Fig 1. 50\% majority rule consensus tree of MrBayes analysis of Neotropical Clade 2 (NC2) of Begonia. Dotted lines indicate posterior clade probabilities $<0.85$. P, perenniation of species in NC2: blue, tuberous; green, rhizomatous; yellow, upright stems. G, geographic range of species in NC2: red, western South American; pink, eastern South America; light blue, Central America and Mexico. 


\title{
Taxonomic Treatment
}

\author{
Class Equisetopsida C.Agardh (Agardh et al. 1825) \\ Subclass Magnoliidae Novák ex Takht. (Takhtajan 1967) \\ Superorder Rosanae Takht. (Takhtajan 1967) \\ Order Cucurbitales Juss. ex Bercht. \& J.Presl (von Berchtold \& Presl 1820) \\ Family Begoniaceae C.Agardh (Agardh 1824) \\ Genus Begonia L. (Linnaeus 1753) \\ Begonia sect. Microtuberosa Moonlight \& Tebbitt sect. nov. \\ http://www.ipni.org/urn:1sid:ipni.org:names:77160200-1
}

\section{Diagnosis}

Begonia sect. Microtuberosa sect. nov. is most closely related to B. sect. Trachelocarpus and three species of B. sect. Gaerdtia. Both of these sections are endemic to eastern Brazil and differ markedly from sect. Microtuberosa sect. nov. in both their habit and floral characteristics (see Table 1). However, all three sections share their filaments fused at least at the base and $B$. sect. Microtuberosa sect. nov. further shares its androecium morphology with $B$. sect. Pereira and its lack of bracteoles with $B$. sect. Trachelocarpus. The majority of both floral and vegetative characters are, however, markedly different among the three sections.

Begonia sect. Microtuberosa sect. nov. is readily identified as the only Neotropical section of Begonia with male flowers with four or fewer stamens, and the combination of ovaries with two or three locules and entire placentas, and a tuberous habit.

\section{Etymology}

The name 'Microtuberosa' emphasises the diminutive and tuberous habit of the type species.

\section{Type species}

Begonia elachista Moonlight \& Tebbitt sp. nov.

\section{Description}

Caulescent, tuberous herbs, perennial. Stems erect. Stipules persistent, entire. Leaves alternate, 2-4(-6), basifixed, blade symmetrical or subsymmetrical, veins palmate. Inflorescence axillary, an asymmetric dichasial cyme, protandrous, bracts persistent. Male flowers: with 2-4 free perianth segments; stamens 2 or 4, filaments united into a column for more than half their length, anthers elliptic, dehiscing via lateral slits, connective not projecting. Female flowers: bracteoles absent, with $2-3$ free perianth segments; ovary and fruit with 2-3 wings, wings equal, 2-3-locular, placentas entire, bearing ovules on both surfaces; styles $2-3$, free to base, bifid from about $2 / 3$ their height, stigmatic papillae in a once spirally twisted band. Fruit a capsule. Seeds not examined.

\section{Distribution}

On a limestone outcrop in lowland Amazonian Peru to the east of the Chemillén Cordillera at an altitude of $430 \mathrm{~m}$. 
Table 1. Comparison between Begonia sect. Microtuberosa Moonlight \& Tebbitt sect. nov. and closely related sections.

\begin{tabular}{|c|c|c|c|}
\hline Character & B. sect. Microtuberosa & B. sect. Pereira & B. sect. Trachelocarpus \\
\hline Habit & Tuberous, stems erect & $\begin{array}{l}\text { Lacking tubers or } \\
\text { rhizomes, stems erect }\end{array}$ & $\begin{array}{l}\text { Rhizomatous (creeping up } \\
\text { the side of a tree), lacking } \\
\text { an erect stem }\end{array}$ \\
\hline Leaves & Alternate & Alternate & $\begin{array}{l}\text { Whorled at the apex of } \\
\text { rhizome }\end{array}$ \\
\hline Venation & Palmate & Pinnate, palmate-pinnate & Pinnate \\
\hline Inflorescence & Bisexual & Bisexual & Separate male and female \\
\hline Bracteoles & Absent & $\begin{array}{l}\text { Absent or } 2 \text { spaced from } \\
\text { the base of the ovary }\end{array}$ & Absent \\
\hline Androecium & $\begin{array}{l}\text { Filaments fused for more } \\
\text { than half their length; } 2 \text { or } \\
4 \text { stamens; anthers elliptic, } \\
\text { dehiscing through lateral } \\
\text { slits }\end{array}$ & $\begin{array}{l}\text { Filaments fused for less } \\
\text { than half their length; } \\
\text { stamens many; anthers } \\
\text { obovate, dehiscing } \\
\text { through lateral slits }\end{array}$ & $\begin{array}{l}\text { Filaments entirely fused } \\
\text { into a column; stamens } \\
\text { many; anthers obovate, } \\
\text { dehiscing through lateral } \\
\text { pores }\end{array}$ \\
\hline Male perianth & $2-4$ tepals & 4 tepals & 2 tepals \\
\hline Ovaries & $\begin{array}{l}2-3 \text { locular with } 2-3 \\
\text { styles; } 1 \text { placental branch } \\
\text { per locule }\end{array}$ & $\begin{array}{l}3 \text { locular with } 3 \text { styles; } \\
2 \text { placental branch } \\
\text { per locule }\end{array}$ & $\begin{array}{l}3 \text { locular with } 3 \text { styles; } \\
1 \text { placental branch per } \\
\text { locule }\end{array}$ \\
\hline Female perianth & $2-3$ tepals & 5 tepals & 3 tepals \\
\hline
\end{tabular}

\section{Begonia elachista Moonlight \& Tebbitt sp. nov. sect. Microtuberosa http://www.ipni.org/urn:1sid:ipni.org:names:77160201-1}

Figs 2, 3

\section{Diagnosis}

Begonia elachista sp. nov. is a highly distinct species with an unusual combination of features that is easily recognized as the only Peruvian species of Begonia that reaches maturity at fewer than $5 \mathrm{~cm}$ in height. It is also unique within Peru in having ovate leaves smaller than $3 \times 3 \mathrm{~cm}$ and a combination of entire placentae and a tuberous habit.

\section{Etymology}

The epithet 'elachista' comes from the Greek for 'least' and emphasizes the diminutive size of this species, which is the smallest known species of Begonia.

\section{Type}

PERU: Region Pasco, Prov. Oxapampa, Dist. Palcazu, Parque Nacional Yanachaga-Chemillén, sector Paujil, $150 \mathrm{~m}$ from entrance to Las Cavernas on trail from Paujil, $10^{\circ} 20^{\prime} 40^{\prime \prime} \mathrm{S}, 75^{\circ} 15^{\prime} 1^{\prime \prime} \mathrm{W}, 432 \mathrm{~m}, 25$ Feb. 2016, Moonlight \& Daza 318 (holo-: MOL; iso-: E, MO, USM). 

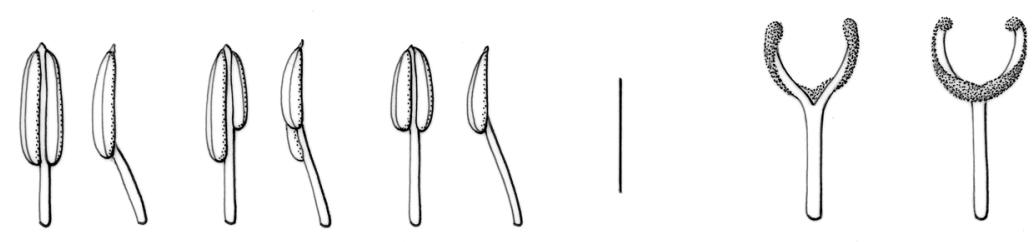

$\mathrm{E}$

$\mathrm{F}$
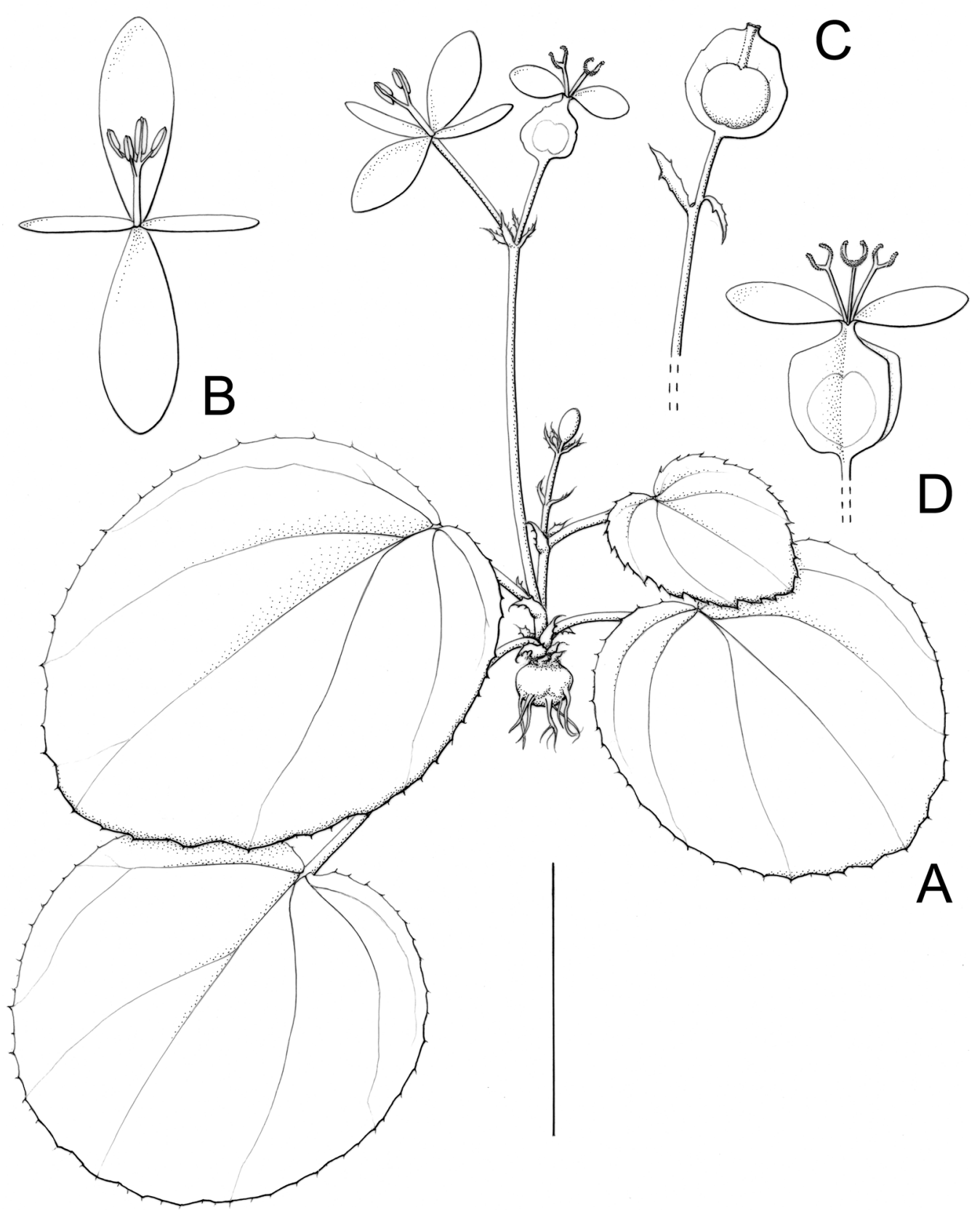

A

Fig 2. Begonia elachista Moonlight \& Tebbitt sp. nov. A. Habit. B. Male flower, front view. C. Branch of infructescence. D. Female flower, side view. E. Stamens, front and side view. F. Style, front and back view. Scale bars: A-D $=1 \mathrm{~cm} ; \mathrm{E}-\mathrm{F}=1 \mathrm{~mm}$. Drawn by Claire Banks. From P. Moonlight \& A. Daza $318(\mathrm{E})$. 


\section{Additional material}

PERU: Region Pasco, Prov. Oxapampa, Dist. Palcazu, Parque Nacional Yanachaga-Chemillén, sector Paujil, Quebrada Tunel, $10^{\circ} 20^{\prime}$ S, $75^{\circ} 15^{\prime} \mathrm{W}, 429$ m, 17 Mar. 2008, Vásquez, Monteagudo, Huamantupa \& A. Peña 34030 (E, HOXA, HUT, MO, USM).

\section{Description}

Caulescent, tuberous herb. Tuber subglobose, $1-2 \mathrm{~mm}$ in diam. Stems 1-3 per tuber, erect, ca $0.2 \mathrm{~mm}$ in diam., 5-30 mm long, unbranched, internodes $1.5-7.5 \mathrm{~mm}$ long, glabrous, light green. Stipules persistent, narrowly lanceolate, $0.5-1.5 \times 0.2-0.5 \mathrm{~mm}$, apex acuminate, aristate, terminal hair ca $0.4 \mathrm{~mm}$ long, margin entire, with 1-2 ciliate hairs to $0.2 \mathrm{~mm}$ on each side. Leaves $1-4$, alternate, basifixed; petiole orientated in same direction as the main vein of blade, $8-25 \mathrm{~mm}$ long, glabrous, blade symmetrical to subsymmetric, ovate to suborbicular, $8-30 \times 7-25 \mathrm{~mm}$, membranous, apex obtuse, base cordate, basal lobes not overlapping, sinus $0.5-2 \mathrm{~mm}$ deep, margin irregularly crenate, ciliate, the hairs to $0.3 \mathrm{~mm}$, upper surface glabrous, light grey-green, lower glabrous, light grey-green, veins palmate, 5-7, secondary veins indistinct. Inflorescences $1-2$, axillary, arising from axis of each leaf, erect, an asymmetric dichasial cyme, with 1-2 branches, bearing up to 2 male flowers and up to 2 female flowers, usually protandrous but basal-most female flower often opening concurrently with the apical male flower; peduncle 5-40 mm long, glabrous; pedicels of male flowers 2-6 mm long, glabrous; pedicels of female flowers $1-5 \mathrm{~mm}$ long, glabrous; bracts persistent, elliptic, $1.5-2.5 \times 0.1-0.3 \mathrm{~mm}$, apex acuminate, margin entire, glabrous or with up to 2 ciliate hairs to $0.2 \mathrm{~mm}$ on each side, dark brown.

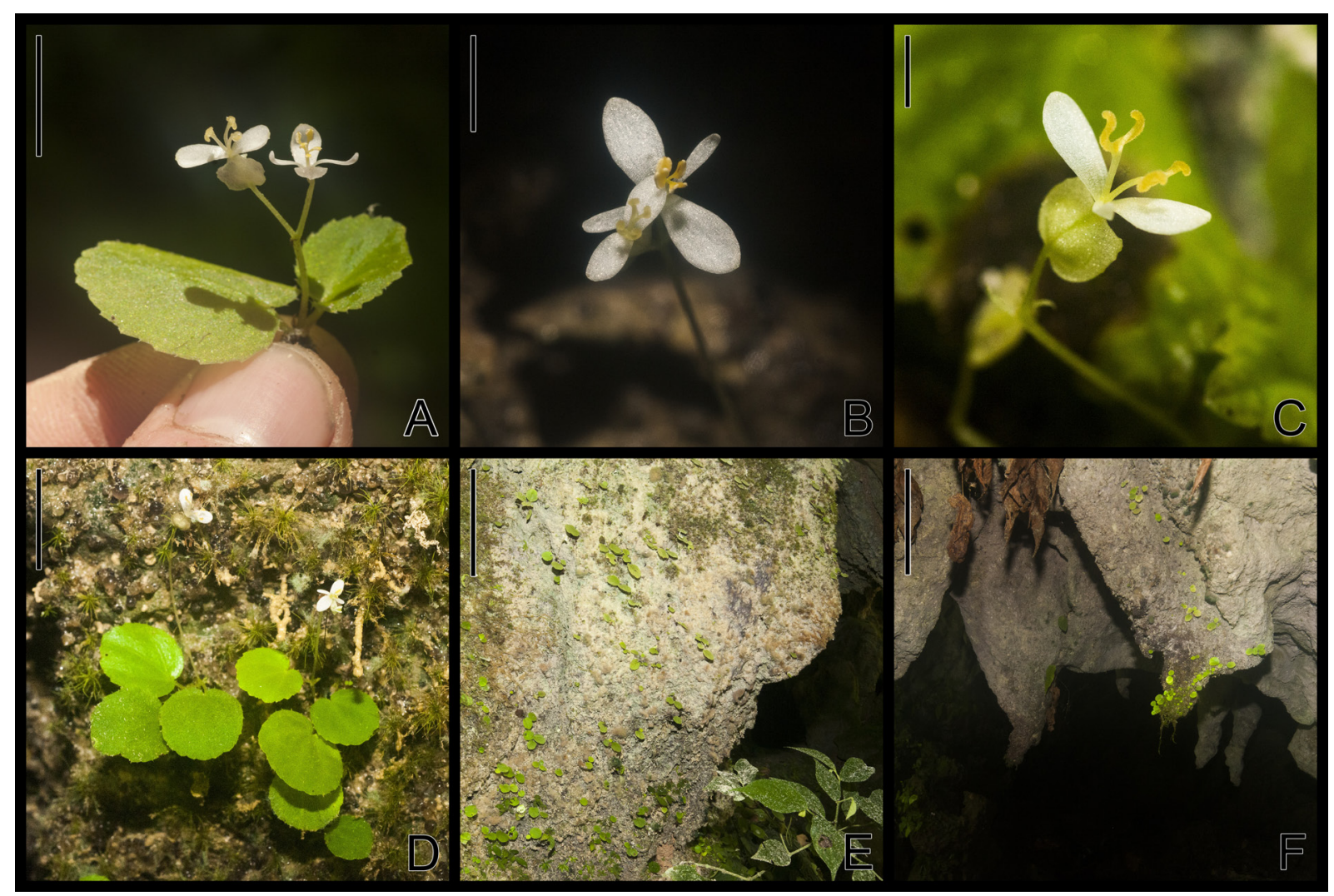

Fig 3. Begonia elachista Moonlight \& Tebbitt sp. nov. A. Whole plant. B. Male and female flower, front view. C. Female flower, side view. D. Habit and associated vegetation. E-F. Habitat and wild population. Scale bars: $\mathrm{A}=1 \mathrm{~cm} ; \mathrm{B}=5 \mathrm{~mm} ; \mathrm{C}=2 \mathrm{~mm} ; \mathrm{D}=2 \mathrm{~cm}$; $-\mathrm{F}=10 \mathrm{~cm}$. Photographed by Peter Moonlight. All from P. Moonlight \& A. Daza 318 (E). 
Male flowers: tepals 2-4, spreading, white, outer two lanceolate to oblanceolate, $3-7.5 \times 1-2.5 \mathrm{~mm}$, apex obtuse to rounded, margin entire, glabrous, inner 1-2 elliptic if present, 3-4 $\times 0.75-1.25 \mathrm{~mm}$, apex obtuse to rounded, margin entire, glabrous; stamens 2 or 4 , yellow, filaments $0.25-0.75 \mathrm{~mm}$ long, united on a $0.75-1 \mathrm{~mm}$ column, anthers elliptic, $0.75-1.5 \mathrm{~mm}$ long, often with long and short thecae on the same anther, dehiscing via lateral slits, connectives not projecting, symmetrically basifixed. Female flowers: bracteoles absent; tepals not persisting in fruit, 2 or rarely 3 , spreading, white, narrowly elliptic to oblanceolate, equal, $3-4.5 \times 0.75-2.5 \mathrm{~mm}$, apex obtuse to rounded, margin entire, glabrous; ovary body ovoid, $1.5-2.5 \times 1-2.5 \mathrm{~mm}$, glabrous, white, subequally $2-3$-winged, wings rounded-oblong, apical edge of wing truncate to convex, basal edge rounded, apex acute to obtuse, $2-2.5 \mathrm{~mm}$ long, 1-1.75 mm wide; $2-3$-locular, placentas entire, bearing ovules on both surfaces; styles $2-3$, yellow, free to base, $2-3 \mathrm{~mm}$ long, bifid from about $2 / 3$ their height, stigmatic papillae in a once spirally twisted band. Fruiting pedicel to $5 \mathrm{~mm}$ long. Fruit body globose, to $1.5-2.5 \times 2-2.5 \mathrm{~mm}$, glabrous, drying brown, wings same shape and size as in ovary. Seeds not examined.

\section{Distribution and habitat}

Begonia elachista sp. nov. is known only from the type locality in the Peruvian region of Pasco (Oxapampa Province) and has been collected on calcareous rocks by the entrance to a cave within primary lowland Amazonian forest, at an altitude of $430 \mathrm{~m}$. It was observed growing on rocks free from other vascular plants in association with various bryophyte species in the almost continual shade of the surrounding forest.

\section{Conservation status}

The known range of B. elachista sp. nov. consists of the area immediately around a single cave mouth and nearby limestone outcrops in sector Paujil of Parque Nacional Yanachaga-Chemillén (AOO $<1 \mathrm{~km}^{2}$ ). There are no other known limestone outcrops in sector Paujil of Parque Nacional Yanachaga-Chemillén or the surrounding areas thus its range is likely limited to this site. Around 5,000 plants are found at this locality and the population appeared stable during fieldwork in February 2016. Although the area is currently protected and tourists are prohibited from visiting the site, the national park authorities are considering building a tourist trail to the cave. The resulting increased footfall would put considerable pressure on the species' habitat and inevitably decrease the population size. Accordingly, we classify B. elachista sp. nov. as Critically Endangered: CR B2 ab(iii) (IUCN 2001).

\section{Discussion}

The tuberous habit and western South American range of $B$. elachista sp. nov. suggest a close relationship with other tuberous Andean species of Begonia but this is not supported by our analysis. The majority of tuberous Andean Begonia species are currently classified in B. sect. Eupetalum, which is distinguished by its geophytic tubers or fleshy rhizomes and relatively large flowers (Doorenbos et al. 1998; Tebbitt 2015). All other tuberous Andean species are classified within B. sect. Barya, B. sect. Knesebeckia and $B$. sect. Quadriperigonia, and all four sections differ from B. elachista sp. nov. in a suite of characters including their bifid placentae (except $B$. lutea L.B.Sm. \& B.G.Schub.), more numerous stamens and female tepals, and much larger size. We resolve $B$. sect. Microtuberosa sect. nov. as distantly related to all tuberous species of Andean Begonia and most closely related to rhizomatous and scandent sections from southeast South America. The morphological differences between B. sect. Microtuberosa sect. nov. and these sections are outlined above (Table 1) and, in combination with the placement of B. elachista sp. nov. outside of these sections, strongly support the description of a new section.

The large morphological disparity between B. elachista sp. nov. and its nearest relatives is typical of that found in limestone cave endemics (Chung et al. 2014). Such species are typically small, often tuberous or rhizomatous, and usually have relatively symmetrical leaves and small, white flowers. Examples of 
this syndrome in Begonia are found across sections and continents and include B. antsingyensis Humb. ex Keraudren \& Bosser sect. Quadrilobaria A.DC. (Madagascar); B. cavum Ziesenh. sect. Knesebeckia (Klotzsch) A.DC. (Mexico); B. hoehneana Irmsch. sect. Unassigned (Brazil); B. exigua Irmsch. sect. Begonia (Brazil); B. minuscula Aver. sect. Reichenheimea (Klotzsch) A.DC. (Vietnam); B. schulziana Urb. \& Ekman sect. Begonia (Haiti); B. speluncae Ridl. sect. Reichenheimea (Klotzsch) A.DC. (Borneo); and many others. This striking convergence among unrelated Begonia species on similar substrates in Begonia is worthy of further investigation.

That $B$. sect. Microtuberosa sect. nov. is nested within a group of eastern Brazilian species suggests it represents an independent dispersal across the Amazon basin, in addition to those identified in Moonlight et al. (2015). The majority of lowland Amazonia represents unsuitable habitat for most Begonia species but the genus appears to have dispersed across the area multiple times. The discovery of a further dispersal event highlights the abundance of 'rare' long-distance dispersal events within Begonia.

Begonia elachista sp. nov. is one of a number of recently described species of Peruvian Begonia. The number of species known from this country has risen from the 34 covered in the Flora of Peru (Smith \& Schubert 1941) to more than 75 today (Hughes et al. 2015). This continued rapid rate of species discovery suggests many more species may remain undiscovered within the country, particularly in limestone areas.

A number of species are contenders for the world's smallest Begonia, and many have been designated epithets emphasising their diminutive statures. The first of these was B. minor Jacq. in 1787, although in this case the name only implied it was slightly smaller than the 20 or so species previously described, and it still grows to more than $1 \mathrm{~m}$. Perhaps the most delicate known Begonia species is the Malaysian B. sibthorpioides Ridl., whose leaves and flowers are both smaller than those of B. elachista sp. nov.; however, the stem of $B$. sibthorpioides trails to $10 \mathrm{~cm}$. Malagasy Begonia also include a number of tiny species, including $B$. leandrii Humb., $B$. nana L'Hér. and B. perpusilla A.DC., while the smallest mainland African species is $B$. wilksii Sosef, but all exceed the $3 \mathrm{~cm}$ total height of B. elachista sp. nov. in either their inflorescence height or petiole length. The recently described Vietnamese $B$. minuscula Aver. and Sumatran B. lilliputana M.Hughes are both small, but the rhizomes of the former reach $6 \mathrm{~cm}$ while the leaf length of the latter equals the entire height of B. elachista sp. nov. Begonia sleumeri L.B.Sm. \& B.G.Schub. is particularly notable in being a small tuberous species from Andean South America. This Argentinian species has smaller leaf blades of a similar size $(1-3.1 \times 1.4-4.6 \mathrm{~cm})$ to B. elachista sp. nov. but has larger tubers $(0.5-2 \mathrm{~cm}$ in diam.), sometimes has taller stems (up to $4.5 \mathrm{~cm}$ tall), often has longer petioles $(1.2-5.3 \mathrm{~cm}$ long), and almost always has larger flowers. We believe B. elachista sp. nov. is the smallest known Begonia species in the world.

\section{Acknowledgements}

The authors are grateful to the curators of AAU, B, BKL, BM, BR, BRIT, C, CAS, CGE, COL, CPUN, CUZ, E, E-GL, F, G, G-BOISS, G-DC, G-DEL, GB, GH, GOET, HOXA, HUT, K, LIL, LPB, MEDEL, MO, MOL, MOL-WEB, NY, OXF, P, QCA, QCNE, QPLS, S, SEL, TEX, UC, US, USM, USZ, W, and $\mathrm{Z}$ for loaning material or allowing us to work in their herbaria. We thank the Ministerio del Ambiente del Perú for granting us permission to conduct the fieldwork and collect specimens and the University of Edinburgh Davis Expedition Fund and the James and Eve Bennett Trust for funding the fieldwork. We also thank Claire Banks for providing the artwork and Aniceto Daza for his assistance in the field. This manuscript forms part of PM's PhD research supported by the M.L. MacIntyre Begonia Trust. This research was carried out at the Royal Botanic Garden Edinburgh, supported by the Scottish Government's Rural and Environment Science and Analytical Services Division. 


\section{References}

Agardh C.A. 1824. Aphorismi Botanici. Literis Berlingianis, Lund.

Agardh C.A., Holmberg L.P. \& Lundstrom P.M. 1825. Classes Plantarum. Literis Berlingianis, Lund.

Berchtold B.V. von \& Presl J.S. 1820. O přirozenosti rostlin, aneb rostlinár, obsahugjcj: gedánj on žiwobytj rostlinném pro sebe a z ohledu giných žiwotů, podlé stawu nyněgssjho znánj; $k$ rozssjřenj přirodnictwj; w potaženj na užitečnost $w$ rolnictwj, hospodárstwj, řemeslech, uměnj $i$ obchodu a w wztahowánj obzwlásstnjm na lekařstwj. Enders, Prague.

Candolle A.C.P. de 1906. Materiaes para a flora amazonica. Boletim do Museo Geoldi de Historia Natural e Ethnographia. Belém 4: 593.

Chung K.-F., Leong W.-C., Rubite R.R., Repin R., Kiew R., Liu Y \& Peng C-I. 2014. Phylogenetic analyses of Begonia sect. Coelocentrum and allied limestone species of China shed light on the evolution of Sino-Vietnamese karst flora. Botanical Studies 55 (1): 1-15. https://doi.org/10.1186/1999-3110-55-1

Darriba D., Taboada G.L., Doallo R. \& Posada D. 2012. jModelTest 2: more models, new heuristics and parallel computing. Nature Methods 9 (8): 772. http://dx.doi.org/10.1038/nmeth.2109

Doorenbos J., Sosef M. \& De Wilde J.J.F.E. 1998. The sections of Begonia including descriptions, keys and species lists (studies in Begoniaceae VI). Wageningen Agricultural University Papers 98 (2): 1-266.

Hall T.A. 1999. BioEdit: a user-friendly biological sequence alignment editor and analysis program for Windows 95/98/NT. Nucleic Acids Symposium Series 41: 95-98.

L’Héritier de Brutelle C.L. 1788. Begonia octopetala. Stirpes Novae aut Minus Cognitae: 101.

Huelsenbeck J.P. \& Ronquist F. 2001. MrBayes: Bayesian inference of phylogenetic trees. Bioinformatics 17 (8): 754-745. http://dx.doi.org/10.1093/bioinformatics/17.8.754

Hughes M., Moonlight P.W., Jara-Muñoz A., Tebbitt M.C. \& Pullan M. 2015 and continously updated. Begonia Resource Centre. Online database available at http://elmer.rbge.org.uk/begonia/ [accessed 15 Aug. 2016].

IUCN 2001. IUCN Red List Categories: Version 3.1. IUCN Species Survival Commission, Cambridge. Available from http://www.iucnredlist.org/technical-documents/categories-and-criteria/2001categories-criteria [accessed 20 Aug. 2016].

Linnaeus C. 1753. Caroli Linnaei ... Species plantarum: exhibentes plantas rite cognitas, ad genera relatas, cum differentiis specificis, nominibus trivialibus, synonymis selectis, locis natalibus, secundum systema sexuale digestas ... Laurentii Salvii, Stockholm.

Moonlight P.W., Richardson J.E., Tebbitt M.C., Thomas D.C., Hollands R., Peng C.-I \& Hughes M. 2015. Continental-scale diversification patterns in a megadiverse genus: the biogeography of Neotropical Begonia. Journal of Biogeography 42 (6):1137-1149. http://dx.doi.org/10.1111/jbi.12496

Rambaut A. \& Drummond A.J. 2013. Tracer v1.5, Available from http://tree.bio.ed.ac.uk/software/ $\underline{\text { tracer/ }}$

Smith L.B. \& Schubert B.G. 1941. Begoniaceae. Flora of Peru 13 (4): 181-202.

TakhtajanA.L. 1967. Sistema ifilogeniia tsvetkovykhrastenii (Systema et Phylogenia Magnoliophytorum). Soviet Science Press, Moscow.

Tebbitt M.C. 2011. A new and unusual xerophytic species of Begonia (Begoniaceae) from Peru. Edinburgh Journal of Botany 68 (2):177-182. http://dx.doi.org/10.1017/S0960428611000096 
Tebbitt M.C. 2015. Two new species of Andean tuberous Begonia in the B. octopetala group (Begoniaceae). Novon: A Journal for Botanical Nomenclature 23 (4): 479-489. http://dx.doi. org $/ 10.3417 / 2013027$

Tebbitt M.C. 2016. Two new species of Andean Begonia (Begoniaceae). Edinburgh Journal of Botany 73 (1):143-152. http://dx.doi.org/10.1017/S0960428615000335

Tebbitt M.C., Toapanta A., C.E. \& Pérez Á.J. 2015. Taxonomy of Begonia serotina (Begoniaceae) and allied species. Edinburgh Journal of Botany 72 (3): 343-352. http://dx.doi.org/10.1017/ $\underline{\mathrm{S} 0960428615000049}$

Manuscript received: 30 August 2016

Manuscript accepted: 29 November 2016

Published on: 17 February 2017

Topic editor: Koen Martens

Desk editor: Connie Baak

Printed versions of all papers are also deposited in the libraries of the institutes that are members of the EJT consortium: Muséum national d'Histoire naturelle, Paris, France; Botanic Garden Meise, Belgium; Royal Museum for Central Africa, Tervuren, Belgium; Natural History Museum, London, United Kingdom; Royal Belgian Institute of Natural Sciences, Brussels, Belgium; Natural History Museum of Denmark, Copenhagen, Denmark; Naturalis Biodiversity Center, Leiden, the Netherlands. 
Appendix. List of voucher specimens and Genbank accession numbers used in phylogenetic analyses.

\begin{tabular}{|c|c|c|c|c|c|}
\hline \multirow[t]{2}{*}{ Species } & \multirow[t]{2}{*}{ Section } & \multirow[t]{2}{*}{ Voucher specimen } & \multicolumn{3}{|c|}{ Genbank voucher } \\
\hline & & & $n d h A$ intron & ndhF-rpl32 & Rpl32-trnL \\
\hline Begonia dregei & Augustia & McLellan 415 (E) & JF756338 & JF756422 & JF756506 \\
\hline Begonia sutherlandii & Augustia & Thomas 08-140(E) & JF756337 & JF756421 & JF756505 \\
\hline Begonia boliviensis & Barya & Forrest $182(\mathrm{E})$ & JF756346 & JF756430 & JF756514 \\
\hline Begonia monadelpha & Barya & Sarkinen 2205 (E) & KP713005 & KP713117 & KY070215 \\
\hline Begonia cyathophora & Cyathocnemis & no voucher & KP713075 & KP713171 & KP713255 \\
\hline Begonia clarkei & Eupetalum & Tebbitt $824(\mathrm{E})$ & KX756293 & KX756304 & KY070198 \\
\hline Begonia froebelii & Eupetalum & Tebbitt 789 (COL) & KX756288 & KX756305 & KY070199 \\
\hline Begonia geraniifolia & Eupetalum & Moonlight $116(\mathrm{E})$ & KX756283 & KX756311 & KY070205 \\
\hline Begonia lutea & Eupetalum & Jara AMB 332 (COL) & KX756287 & KX756320 & $\mathrm{n} / \mathrm{a}$ \\
\hline Begonia micranthera 1 & Eupetalum & Sarkinen $2029(\mathrm{E})$ & KP713032 & KP713204 & $\mathrm{n} / \mathrm{a}$ \\
\hline Begonia micranthera 2 & Eupetalum & Sarkinen 2043 (E) & KP713066 & KP713198 & $\mathrm{n} / \mathrm{a}$ \\
\hline Begonia tumbezensis & Eupetalum & Tebbitt 770 (QCNE) & $\mathrm{n} / \mathrm{a}$ & KX756312 & $\mathrm{n} / \mathrm{a}$ \\
\hline Begonia weberbaueri & Eupetalum & Sarkinen $2216(\mathrm{E})$ & KP713024 & KP713102 & KP713340 \\
\hline Begonia edmundoi & Gaerdtia & Forrest $196(\mathrm{E})$ & KР712994 & KP713216 & KP713261 \\
\hline Begonia lubbersii & Gaerdtia & Forrest 194 (E) & KP712981 & KP713100 & KP713237 \\
\hline Begonia pseudolubbersii & Gaerdtia & $G B G$ 045-023-92 (GBG) & KP713072 & KP713203 & KP713329 \\
\hline Begonia carolineifolia & Gireoudia & Tebbitt $80(\mathrm{BKL})$ & KP713033 & KP713103 & KP713244 \\
\hline Begonia conchifolia & Gireoudia & Tebbitt 89 (BKL) & KP713021 & KP713083 & KP713305 \\
\hline Begonia multinervia & Gireoudia & Tebbitt 131 (BKL) & KP713023 & KP713163 & KP713258 \\
\hline Begonia nelumbiifolia & Gireoudia & Hollands 009 (E) & KP713040 & KP713077 & KP713230 \\
\hline Begonia maurandiae 1 & Gobenia & Jara, A (2758) & KX756291 & KX756313 & KY070206 \\
\hline Begonia maurandiae 2 & Gobenia & Duruisseau s.n. (LBG) & KX756281 & KX756314 & $\mathrm{n} / \mathrm{a}$ \\
\hline Begonia hitchcockii & Gobenia & Moonlight $123(\mathrm{E})$ & KX756290 & KX756315 & KY070207 \\
\hline Begonia sp. sect. Gobenia & Gobenia & EQ-JD-04 (LBG) & KX756292 & KX756316 & KY070208 \\
\hline Begonia fissistyla & Hydristyles & Forrest 157 (E): E00205201 & KP713051 & KP713173 & KP713250 \\
\hline Begonia aff. incarnata & Knesebeckia & Twyford $587(\mathrm{E})$ & KP713065 & KP713090 & KP713232 \\
\hline Begonia bifurcata 1 & Knesebeckia & Tebbitt 782 (QCNE) & $\mathrm{n} / \mathrm{a}$ & KX756306 & KY070200 \\
\hline Begonia bifurcata 2 & Knesebeckia & Moonlight $105(\mathrm{E})$ & KX756296 & KX756307 & KY070201 \\
\hline Begonia bifurcata 3 & Knesebeckia & Moonlight 117 (E) & KX756278 & KX756308 & KY070202 \\
\hline Begonia bullatifolia 1 & Knesebeckia & Peng 21323 (HAST) & KP713073 & KP713128 & $\mathrm{n} / \mathrm{a}$ \\
\hline Begonia bullatifolia 2 & Knesebeckia & Duruisseau s.n. (LBG) & KX756303 & $\mathrm{n} / \mathrm{a}$ & KY070224 \\
\hline Begonia erythrocarpa & Knesebeckia & Sarkinen $2058(\mathrm{E})$ & KP713031 & KP713140 & $\mathrm{n} / \mathrm{a}$ \\
\hline Begonia incarnata & Knesebeckia & Peng 20869 (HAST) & KP713069 & KP713076 & $\mathrm{n} / \mathrm{a}$ \\
\hline
\end{tabular}


Appendix (cont.).

\begin{tabular}{|c|c|c|c|c|c|}
\hline \multirow[t]{2}{*}{$\overline{\text { Species }}$} & \multirow[t]{2}{*}{ Section } & \multirow[t]{2}{*}{ Voucher specimen } & \multicolumn{3}{|c|}{ Genbank voucher } \\
\hline & & & $n d h A$ intron & ndhF-rpl32 & Rpl32-trnL \\
\hline Begonia ludwigii & Knesebeckia & Peng 23333 (HAST) & KP712990 & KP713112 & $\mathrm{n} / \mathrm{a}$ \\
\hline Begonia maynensis & Knesebeckia & Peng s.n. (HAST) & KP713063 & KP713141 & $\mathrm{n} / \mathrm{a}$ \\
\hline Begonia parcifolia & Knesebeckia & Tebbitt 783 (QCNE) & KX756277 & KX756317 & KY070209 \\
\hline Begonia piurensis & Knesebeckia & Moonlight $111(\mathrm{E})$ & KX756276 & KX756318 & KY070210 \\
\hline Begonia santos-limae & Knesebeckia & Peng 21320 (HAST) & KP713016 & KP713126 & $\mathrm{n} / \mathrm{a}$ \\
\hline Begonia serotina & Knesebeckia & Tebbitt 776 (QCNE) & KX756284 & KX756319 & KY070211 \\
\hline Begonia sp. A & Knesebeckia & Moonlight $156(\mathrm{E})$ & KX756295 & KX756322 & KY070214 \\
\hline Begonia sp. B & Knesebeckia & Moonlight $159(\mathrm{E})$ & KX756301 & KX756321 & KY070213 \\
\hline Begonia foliosa & Lepsia & Unknown s.n. (E) E19480286 & KP713060 & KP713176 & KP713310 \\
\hline Begonia elachista & Microtuberosa & Moonlight $318(\mathrm{E})$ & KX756285 & KX756324 & KY070216 \\
\hline Begonia elachista & Microtuberosa & Moonlight $318(\mathrm{E})$ & KX756297 & KX756324 & KY070217 \\
\hline Begonia oaxacana & Parietoplacentlia & no voucher & KX756280 & KX756325 & KY070218 \\
\hline Begonia buddleiifolia & Pilderia & Jara 2599 (E) & KX756286 & KX756327 & KY070220 \\
\hline Begonia glandulifera & Pilderia & Gardner $6608(\mathrm{E})$ & KX756294 & KX756328 & KY070220 \\
\hline Begonia mariannensis & Pilderia & Duruisseau s.n. (LBG) & KX756299 & KX756329 & KY070221 \\
\hline Begonia gracilis & Quadriperigonia & Badcock $9(\mathrm{E})$ & KP713004 & KP713078 & KP713260 \\
\hline Begonia thyrsoidea & Quadriperigonia & Tebbitt $809(\mathrm{E})$ & $\mathrm{n} / \mathrm{a}$ & KX756320 & KY070212 \\
\hline Begonia rossmanniae 1 & Rossmannia & Scherberich 1095 (LBG) & KX756300 & KX756330 & KY070223 \\
\hline Begonia rossmanniae 2 & Rossmannia & Moonlight $315(\mathrm{E})$ & KX756302 & $\mathrm{n} / \mathrm{a}$ & KY070223 \\
\hline Begonia holtonis & Ruizopavonia & Forrest 152 (E): E00205231 & KP713062 & KP713175 & KP713307 \\
\hline Begonia meridensis & Ruizopavonia & Forrest 151 (E): E00205112 & KP713057 & KP713132 & KP713308 \\
\hline Begonia integerrima & Solananthera & Tebbitt 69 (BKL) & KP713000 & KP713099 & KP713242 \\
\hline Begonia radicans & Solananthera & GBG 009-089-95 (GBG) & JF756345 & JF756429 & JF756513 \\
\hline Begonia solananthera & Solananthera & GBG 021-070-04 (GBG) & KP712999 & KP713098 & KP713243 \\
\hline Begonia fulvosetulosa & Trachelocarpus & Sénéchal s.n. (LBG) & KX756279 & KX756331 & KY070225 \\
\hline Begonia herbacea & Trachelocarpus & Forrest 163 (E): E00205153 & KP713015 & KP713202 & KY070225 \\
\hline Begonia lanceolata 1 & Trachelocarpus & no voucher & KP713068 & KP713101 & KP713253 \\
\hline Begonia lanceolata 2 & Trachelocarpus & Sénéchal s.n. (LBG) & KX756289 & KX756332 & KY07022 \\
\hline Begonia cremnophila & Unassigned & Tebbitt 753 (LPB) & KX756282 & KX756309 & KY070204 \\
\hline Begonia urubambensis & Unassigned & Moonlight $244(\mathrm{E})$ & KX756298 & KX756310 & KY070204 \\
\hline Begonia heydei & Urniformia & Peng 22624 (HAST) & KP713030 & KP713114 & $\mathrm{n} / \mathrm{a}$ \\
\hline Begonia imperialis & Weilbachia & Forrest $187(\mathrm{E})$ & KP713008 & KP713088 & KP713228 \\
\hline Begonia purpusii & Weilbachia & Tebbitt 70 (BKL) & KP713028 & KP713087 & KP713251 \\
\hline
\end{tabular}

